ఠ

\title{
Arbekacin: another novel agent for treating infections due to methicillin-resistant Staphylococcus aureus and multidrug-resistant Gram-negative pathogens
}

\author{
This article was published in the following Dove Press journal: \\ Clinical Pharmacology:Advances and Applications \\ 26 September 2014 \\ Number of times this article has been viewed
}

\author{
Tetsuya Matsumoto \\ Department of Microbiology, Tokyo \\ Medical University, Tokyo, Japan
}

\begin{abstract}
Arbekacin sulfate (ABK), an aminoglycoside antibiotic, was discovered in 1972 and was derived from dibekacin to stabilize many common aminoglycoside modifying enzymes. ABK shows broad antimicrobial activities against not only Gram-positive bacteria including methicillinresistant Staphylococcus aureus (MRSA) but also Gram-negative bacteria such as Escherichia coli, Pseudomonas aeruginosa, and Klebsiella pneumoniae. ABK has been approved as an injectable formulation in Japan since 1990, under the trade name Habekacin, for the treatment of patients with pneumonia and sepsis caused by MRSA. The drug has been used in more than 250,000 patients, and its clinical benefit and safety have been proven over two decades. ABK currently shows promise for the application for the treatment of multidrug-resistant Gram-negative bacterial infections such as multidrug-resistant strains of $P$. aeruginosa and Acinetobacter baumannii because of its synergistic effect in combination with beta-lactams.
\end{abstract}

Keywords: synergistic effect, Habekacin, MRSA, multidrug-resistant Gram-negative bacteria

\section{Introduction}

Arbekacin (ABK) (Meiji Seika Pharma Co, Ltd, Tokyo, Japan) has the hydroxy aminobutyryl group as its chemical structure and is classified as a kanamycin family aminoglycoside (Figure 1). ${ }^{1} \mathrm{ABK}$ causes membrane damage and binds both to the $50 \mathrm{~S}$ and the $30 \mathrm{~S}$ ribosomal subunits, resulting in codon misreading and inhibition of translation. ${ }^{2} \mathrm{ABK}$ is not inactivated by aminoglycoside-inactivating enzymes such as ( $3^{\prime}$ ) aminoglycosidephosphotransferase (APH), (4') aminoglycoside-adenyltransferase (AAD), or AAD (2") and has a weak affinity for ( $6^{\prime}$-IV) aminoglycoside-acetyltransferase (AAC). Therefore, ABK exhibits antimicrobial activity against Gram-positive and -negative pathogens including strains resistant to gentamicin (GM), tobramycin (TOB), and amikacin (AMK). In particular, ABK has strong antimicrobial potency against methicillin-resistant Staphylococcus aureus (MRSA) and has been used in Japan since 1990 under the trade name Habekacin (Meiji Seika Pharma Co., Ltd. Tokyo, Japan), to treat sepsis and pneumonia caused by MRSA. In addition, Habekacin has also been used in Korea since 2000.

\section{Principal pharmacology (in vitro antibacterial activities)}

ABK showed strong antimicrobial activity against Gram-positive bacteria such as S. aureus ${ }^{3}$ and Staphylococcus epidermidis. ${ }^{4}$ Antibacterial activities of ABK, GM, TOB, and AMK against 54 methicillin-susceptible $S$. aureus clinical isolates were determined 


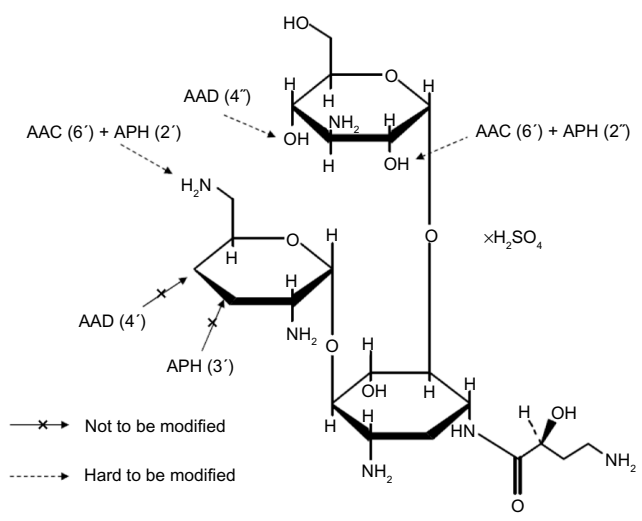

Figure I Structural formula of arbekacin sulfate.

Abbreviations: APH, aminoglycoside-phosphotransferase; AAD, aminoglycosideadenyltransferase; AAC, aminoglycoside-acetyltransferase.

and the results are shown in Table $1 .{ }^{3}$ The minimal inhibitory concentration (MIC) for $90 \%$ of the organisms $\left(\mathrm{MIC}_{90}\right)$ of ABK was $1 \mu \mathrm{g} / \mathrm{mL}$, whereas $\mathrm{MIC}_{90}$ of $\mathrm{GM}$, TOB, and AMK were 4,8 , and $16 \mu \mathrm{g} / \mathrm{mL}$, respectively. ${ }^{3}$ Furthermore, the $\mathrm{MIC}_{90}$ of $\mathrm{ABK}$ against $S$. epidermidis was $0.5 \mu \mathrm{g} / \mathrm{mL}$ and it was stronger than that of AMK $\left(\mathrm{MIC}_{90} 4 \mu \mathrm{g} / \mathrm{mL}\right) .{ }^{4} \mathrm{ABK}$ also has superior antibacterial activity against Gram-negative bacteria including Pseudomonas aeruginosa. ${ }^{3,5}$

The antibacterial activities of ABK against strains producing aminoglycoside-inactivating enzymes were investigated as well as the antibacterial activities of ABK against tested organisms without the influence of aminoglycoside-inactivating enzymes. ${ }^{6}$ The bactericidal effects of ABK against $S$. aureus and Escherichia coli were better than those of AMK and GM, and the bactericidal effects against Klebsiella pneumoniae and P. aeruginosa were comparable with AMK and GM.?

\section{Stability to aminoglycoside- inactivating enzymes}

$\mathrm{ABK}$ was stable to the aminoglycoside-inactivating enzymes produced by MRSA, such as APH, AAD, and AAC. ${ }^{8}$ Although GM, AMK, TOB, and kanamycin (KM) were completely inactivated by $\mathrm{APH}\left(2^{\prime \prime}\right)$, ABK still showed about $50 \%$ activity against APH ( $\left.2^{\prime \prime}\right)$. Furthermore, ABK was not inactivated by AAD (4') and APH (3'), and also showed stability to these enzymes. These results suggest the excellent antibacterial activities of ABK against MRSA strains.

\section{Antibacterial activity against MRSA}

ABK showed the most potent antibacterial effect against clinically isolated MRSA strains among the tested aminoglycosides (GM, TOB, and AMK), and the antibacterial effect of ABK was equivalent to that of vancomycin (VCM)., ${ }^{3,-12}$ Figure 2 shows the cumulative percentage of MIC against MRSA with

Table I In vitro antibacterial activity against aerobic bacteria

\begin{tabular}{|c|c|c|c|c|c|c|c|c|}
\hline \multirow[t]{2}{*}{ Bacterial strain } & \multirow[t]{2}{*}{$(\mu \mathrm{g} / \mathrm{mL})$} & \multicolumn{7}{|c|}{ Antibacterial agent } \\
\hline & & Gentamicin & Tobramycin & Amikacin & Arbekacin & Vancomycin & Teicoplanin & Linezolid \\
\hline Methicillin-resistant & $\mathrm{MIC}_{50}$ & 16 & $\geq 256$ & 16 & 0.5 & 1 & 0.5 & 2 \\
\hline \multirow{2}{*}{$\begin{array}{l}\text { Staphylococcus aureus } \\
(\mathrm{n}=76)\end{array}$} & $\mathrm{MIC}_{90}$ & 128 & $\geq 256$ & 32 & I & 2 & 2 & 2 \\
\hline & Range & 0.125 to $\geq 256$ & 0.25 to $\geq 256$ & I to $\geq 256$ & 0.125 to 4 & 0.5 to 2 & 0.125 to 4 & I to 4 \\
\hline Methicillin-susceptible & $\mathrm{MIC}_{50}$ & 0.25 & 0.5 & 2 & 0.5 & 1 & 0.5 & 2 \\
\hline \multirow[t]{2}{*}{ S. aureus $(n=54)$} & $\mathrm{MIC}_{90}$ & 16 & 8 & 4 & 1 & 2 & I & 2 \\
\hline & Range & 0.125 to 64 & 0.125 to 32 & 0.5 to 8 & 0.125 to 1 & 0.5 to 2 & 0.25 to 2 & I to 4 \\
\hline Streptococcus & $\mathrm{MIC}_{50}$ & 4 & 16 & 32 & 16 & 0.25 & $\leq 0.06$ & I \\
\hline pneumoniae & $\mathrm{MIC}_{90}$ & 8 & 16 & 64 & 32 & 0.5 & 0.125 & I \\
\hline$(n=127)$ & Range & 2 to 16 & 4 to 32 & 16 to 128 & 8 to 64 & 0.125 to 0.5 & $\leq 0.06$ to 0.125 & 0.125 to 2 \\
\hline Haemophilus & $\mathrm{MIC}_{50}$ & 1 & 2 & 4 & 2 & $\mathrm{nt}$ & nt & nt \\
\hline \multirow[t]{2}{*}{ influenzae $(n=123)$} & $\mathrm{MIC}_{90}$ & 1 & 2 & 8 & 4 & $\mathrm{nt}$ & $\mathrm{nt}$ & $\mathrm{nt}$ \\
\hline & Range & 0.125 to 4 & 0.5 to 8 & 0.5 to 8 & 0.5 to 8 & $\mathrm{nt}$ & $\mathrm{nt}$ & $\mathrm{nt}$ \\
\hline Moraxella catarrhalis & $\mathrm{MIC}_{50}$ & 0.125 & 0.25 & 0.5 & 0.125 & 64 & 16 & 8 \\
\hline \multirow[t]{2}{*}{$(\mathrm{n}=70)$} & $\mathrm{MIC}_{90}$ & 0.125 & 0.25 & 1 & 0.25 & 128 & 32 & 8 \\
\hline & Range & $\leq 0.06$ to 0.25 & $\leq 0.06$ to 0.5 & $\leq 0.06$ to 2 & $\leq 0.06$ to 0.5 & 32 to 128 & 8 to 32 & 2 to 16 \\
\hline Klebsiella pneumoniae & $\mathrm{MIC}_{50}$ & 0.25 & 0.5 & I & 0.5 & $\mathrm{nt}$ & $\mathrm{nt}$ & nt \\
\hline \multirow[t]{2}{*}{$(n=78)$} & $\mathrm{MIC}_{90}$ & 0.25 & 0.5 & I & 0.5 & $\mathrm{nt}$ & $\mathrm{nt}$ & $\mathrm{nt}$ \\
\hline & Range & $\leq 0.06$ to 0.5 & $\leq 0.06$ to 8 & 0.125 to 2 & $\leq 0.06$ to 0.5 & nt & nt & nt \\
\hline Pseudomonas & $\mathrm{MIC}_{50}$ & I & 0.5 & 2 & 1 & $\mathrm{nt}$ & $\mathrm{nt}$ & $\mathrm{nt}$ \\
\hline aeruginosa & $\mathrm{MIC}_{90}$ & 8 & 2 & 8 & 8 & $\mathrm{nt}$ & $\mathrm{nt}$ & $\mathrm{nt}$ \\
\hline$(n=103)$ & Range & $\leq 0.06$ to $\geq 256$ & $\leq 0.06$ to $\geq 256$ & 0.125 to 64 & 0.125 to 32 & $\mathrm{nt}$ & $\mathrm{nt}$ & $\mathrm{nt}$ \\
\hline
\end{tabular}

Note: Inoculum size: $10^{6} \mathrm{CFU} / \mathrm{mL}$.

Abbreviations: $\mathrm{nt}$, not tested; $\mathrm{CFU}$, colony forming units; $\mathrm{MIC}$, minimal inhibitory concentration; $\mathrm{MIC}_{90}$, minimal inhibitory concentration for $90 \%$ of the organisms; $\mathrm{MIC}_{50}$, minimal inhibitory concentration for $50 \%$ of the organisms. 


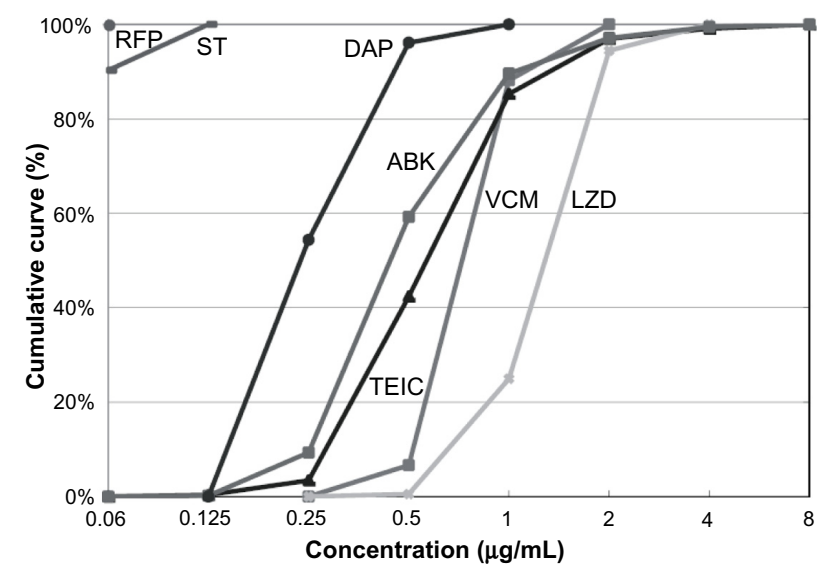

Figure 2 Antibacterial activity against MRSA.

Notes: The surveillance was jointly conducted by the Surveillance Committee of Japanese Society of Chemotherapy, Japanese Association for Infectious Diseases, and Japanese Society for Clinical Microbiology. VCM, TEIC, ABK, and LZD: $n=557$; ST, RFP, and DAP: $n=103$.

Abbreviations: MRSA, methicillin-resistant Staphylococcus aureus; VCM, vancomycin; TEIC, teicoplanin; ABK, arbekacin; LZD, linezolid; ST, sulfamethoxazole-trimethoprim; RFP, rifampicin; DAP, daptomycin.

the antimicrobial susceptibility surveillance conducted in Japan. ${ }^{9-12}$ The antimicrobial activity of ABK was more potent than the other anti-MRSA drugs except daptomycin.

The susceptibility of MRSA to ABK has not changed since 1990 when ABK was launched. In another surveillance, the MICs of ABK, VCM, teicoplanin (TEIC), and linezolid (LZD) against 228 MRSA clinical isolates in Japan were determined. The results showed that $\mathrm{MIC}_{90} / \mathrm{MIC}_{50}$ of $\mathrm{VCM}$ and $\mathrm{ABK}$ had not significantly changed in the period from 1990 to 2006 even though $\mathrm{MIC}_{90}$ of TEIC and LZD were slightly increased during the period. ${ }^{13}$

\section{Bactericidal effect of ABK against MRSA}

ABK also shows concentration-dependent bactericidal activity. ${ }^{14-18}$ Viable counts of MRSA were rapidly decreased in a short period after the addition of $\mathrm{ABK}$ in comparison with those of VCM, TEIC, and LZD (Figure 3). ${ }^{18}$

\section{Post antibiotic effect of ABK}

Post antibiotic effect is another characteristic of aminoglycoside antibiotics. When MRSA was treated either with ABK or VCM with the same concentration, the bactericidal activity of VCM was weaker than ABK, and the post antibiotic effect was shorter compared with ABK. ${ }^{14}$

\section{Inhibition of toxic shock syndrome toxin-I (TSST-I) by ABK}

The effect of ABK, VCM, and TEIC on the production of TSST-1 by MRSA strains has been reported. ${ }^{19}$ In logarithmic

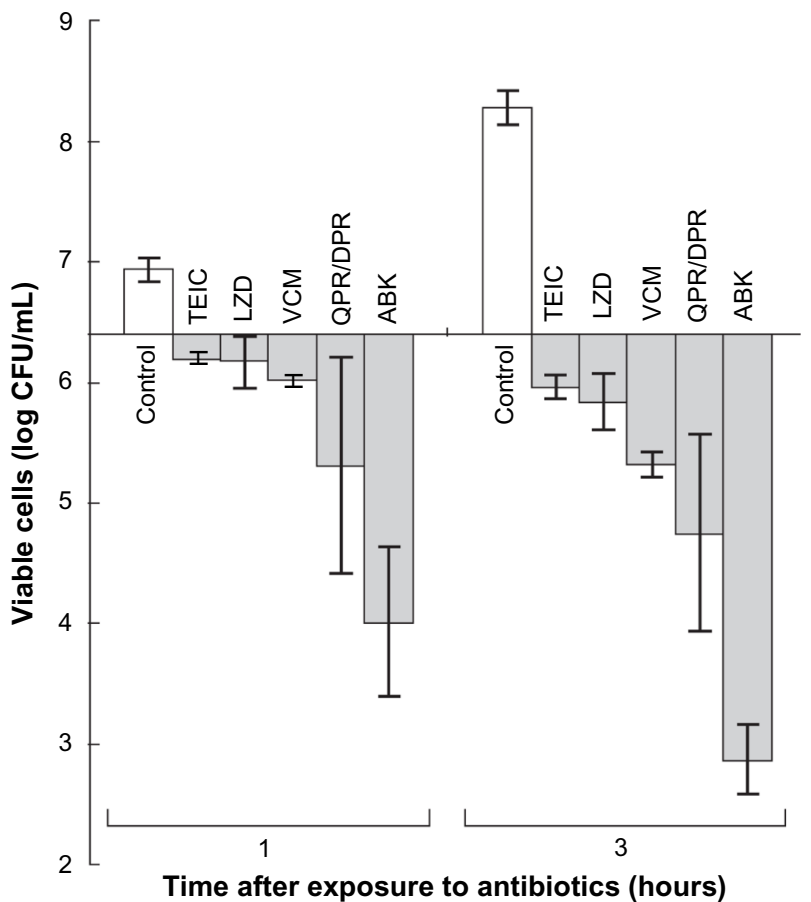

Figure 3 Bactericidal activity of anti-MRSA agents against five MRSA strains. Notes: Boxes and bars indicate mean and SD of viable cell counts. Mean \pm SD of viable cell count (log of $\mathrm{CFU} / \mathrm{mL}$ ) before exposure to antibiotics was $6.40 \pm 0.06$. Abbreviations: MRSA, methicillin-resistant Staphylococcus aureus; TEIC, teicoplanin; LZD, linezolid; VCM, vancomycin; QPR/DPR, quinupristin/dalfopristin; ABK, arbekacin; $\mathrm{SD}$, standard deviation; CFU, colony forming units.

phase cultures, ABK, VCM, and TEIC inhibited TSST-1 production by 85,10 , and $25 \%$, respectively, at the concentration of one fourth of each MIC (Figure 4).

\section{Antibacterial activities against multidrug-resistant $P$. aeruginosa}

Multidrug-resistant strains of $P$. aeruginosa have been an important issue and the strains with the MICs of $\mathrm{AMK} \geq 32 \mu \mathrm{g} / \mathrm{mL}$, imipenem $\geq 16 \mu \mathrm{g} / \mathrm{mL}$, and ciprofloxacin $\geq 4 \mu \mathrm{g} / \mathrm{mL}$ are defined as multidrug-resistant P. aeruginosa (MDRP) in Japan. It is difficult to treat patients with MDRP infections and colistin (CL) may be a good candidate for treatment. Because CL is not approved for clinical use in Japan, many doctors in Japan are interested in combination therapy such as beta-lactam antibiotics and aminoglycoside antibiotics.

Antibiotic combination therapy study groups studied the effective combination regimen against MDRP and demonstrated that ABK plus aztreonam (AZT) was the most promising combination, the other promising regimens were AZT plus AMK and AZT plus GM (Figure 5). ${ }^{20}$

Antibiotic combination therapy study groups also reported that a combination of $\mathrm{ABK}$ plus $\mathrm{AZT}$ showed 
A

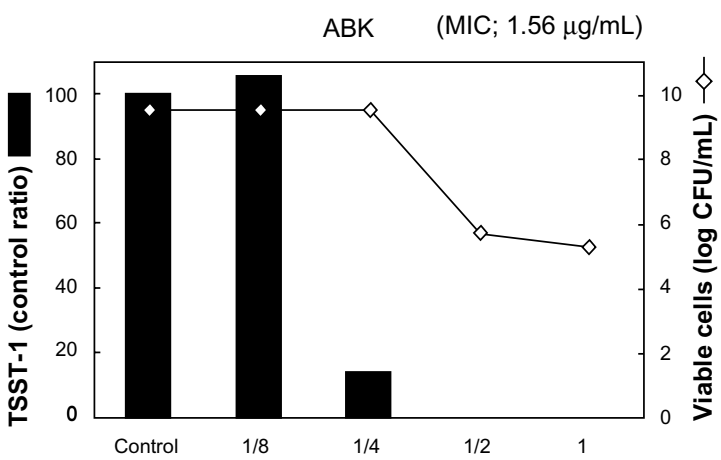

VCM $\quad(M I C ; 1.56 \mu \mathrm{g} / \mathrm{mL})$

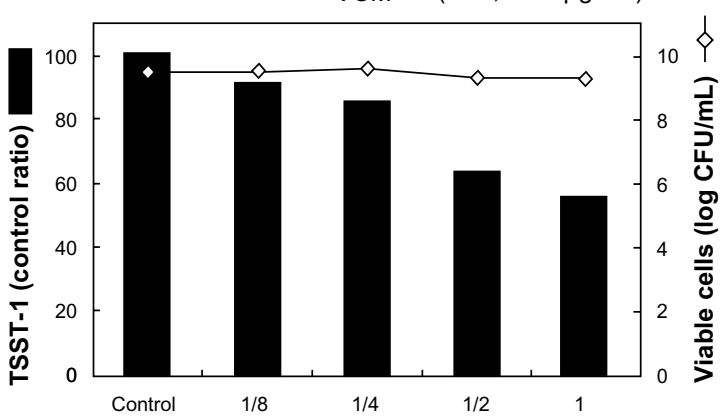

TEIC (MIC; $1.56 \mu \mathrm{g} / \mathrm{mL})$

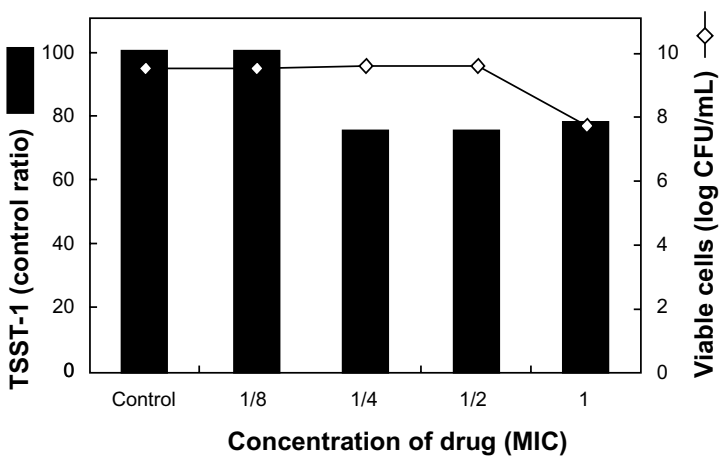

B
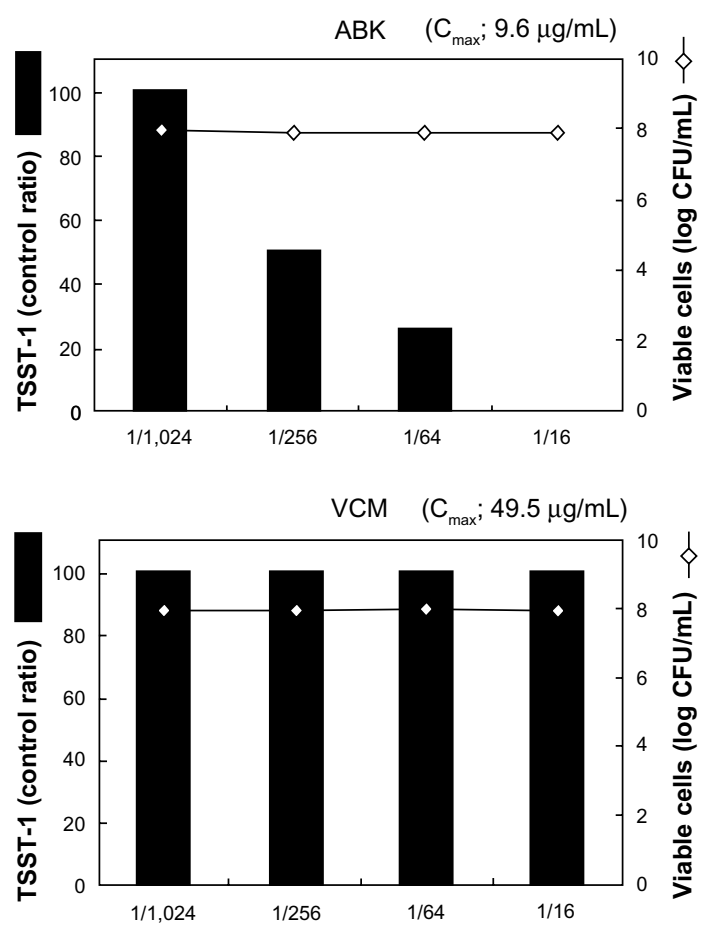

TEIC $\left(C_{\text {max }} ; 71.68 \mu \mathrm{g} / \mathrm{mL}\right)$

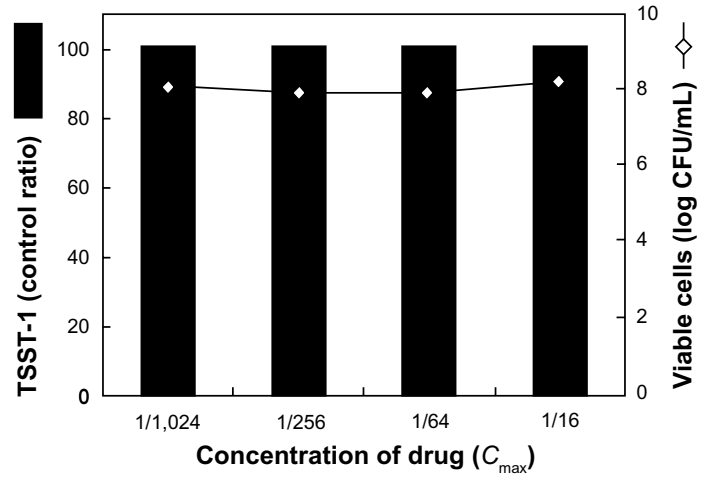

Figure 4 Effect of TSST-I producing ability of MRSA.

Notes: (A) Effect on TSST-I production in logarithmic growth phase; (B) effect on TSST-I production of blood-containing medium. I MIC values of test drugs against S. aureus Sak-I were all $1.56 \mu \mathrm{g} / \mathrm{mL}$. The I/2, I/4, and I/8 MIC values were $0.78,0.39$, and $0.195 \mu \mathrm{g} / \mathrm{mL}$, respectively. $\mathrm{C}_{\max }$ is the maximum concentration of serum after the administration of each drug in humans using the usual dose, and these values were $9.6 \mu \mathrm{g} / \mathrm{mL}$ for ABK, $49.5 \mu \mathrm{g} / \mathrm{mL}$ for VCM and $71.68 \mu \mathrm{g} / \mathrm{mL}$ for TEIC, respectively. Then, I/16, I/64, 1/256 and I/1024 $C_{\text {max }}$ were calculated using the $C_{\text {max }}$ of each drug.

Abbreviations: MRSA, methicillin-resistant Staphylococcus aureus; ABK, arbekacin; VCM, vancomycin; TEIC, teicoplanin; TSST-I, toxic shock syndrome toxin-I; CFU, colony forming units; MIC, minimal inhibitory concentration; $C_{\text {max }}$, maximum concentration.
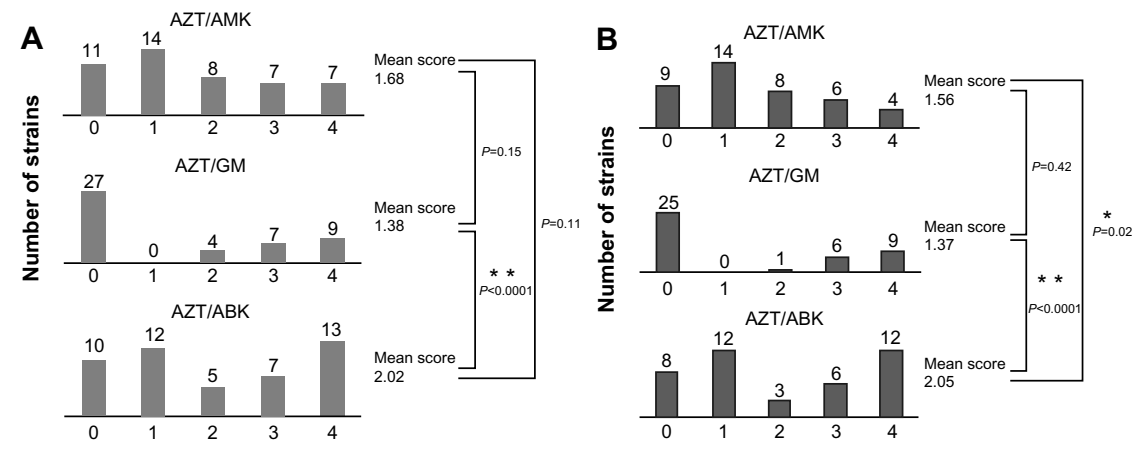

Figure 5 Scoring of combination effect for each drug combination against multidrug-resistant (MDR) Pseudomonas aeruginosa strains. Notes: (A) All 47 MDRPs. (B) $\mathrm{N}=4$ I metallo-beta-lactamase (MBL)-positive MDRP strains.

Abbreviations: MDRP, multidrug-resistant Pseudomonas aeruginosa; AZT, aztreonam; AMK, amikacin; GM, gentamicin; ABK, arbekacin. 
synergistic effects as well as the combinations of CL plus rifampin, and AMK plus AZT (Figure 6). ${ }^{21}$ These results suggest that $A B K$ is a useful agent for MDRP infections used in combination therapies.

\section{Antibacterial activities against multidrug-resistant Acinetobacter baumannii-calcoaceticus}

Recently, ABK has also attracted attention for its antibacterial effect against $A$. baumannii-calcoaceticus. Zapor et al ${ }^{22}$ examined the in vitro antibacterial activity of ABK against $A$. baumannii-calcoaceticus isolated from clinical specimens at The Walter Reed Army Medical Center during the Global War on Terrorism. Additionally, the in vitro MIC of ABK against 200 Acinetobacter baumannii-calcoacetics isolates recovered from wounded soldiers was determined. The median MIC was $2 \mu \mathrm{g} / \mathrm{mL}$ (range: 0.5 to $>64 \mu \mathrm{g} / \mathrm{mL}$ ). A total of $97.5 \%$ of the isolates had ABK MICs of $<8 \mu \mathrm{g} / \mathrm{mL}$ and $86.5 \%$ had MICs of $<4 \mu \mathrm{g} / \mathrm{mL}$. There was no association between the ABK MIC and susceptibility to 16 other antibiotics or the specimen source. Moreover, synergy testing suggested an enhanced effect of ABK-carbapenem combinations. ${ }^{22}$

\section{Efficacy in mouse mixed infection model (in vivo)}

Since ABK has shown potent activities against both MRSA and P. aeruginosa, the effect of ABK in a mixed infection model using MRSA and $P$. aeruginosa was investigated. The median effect dose $\left(\mathrm{ED}_{50}\right)$ that calculated the life and death on 7 days after administration was $19.5 \mathrm{mg} / \mathrm{kg}$ for $\mathrm{ABK}$ and $>100 \mathrm{mg} / \mathrm{kg}$ for VCM. Thus, ABK showed a protective polymicrobial effect on MRSA and P. aeruginosa infections. ${ }^{23}$

\section{Pharmacokinetics in adults}

A multi-center collaborative open clinical study was conducted in patients infected with MRSA to evaluate the efficacy, safety, and the pharmacokinetics-pharmacodynamics
(PK-PD) of ABK. The patients were administered $200 \mathrm{mg}$ of $\mathrm{ABK}$ once daily, and the patients with severe renal dysfunction (creatinine clearance $\geq 80 \mathrm{~mL} / \mathrm{min}$ ) showed changes in the pharmacokinetic parameters such as prolongation of halflife, decrease of total clearance, and increase of area under the curve (0-24 hr) $\left(\mathrm{AUC}_{0-24}\right)$ (Table 2 and Figure $\left.7 \mathrm{~A}\right) .^{24}$

On the other hand, the pharmacokinetics in healthy volunteers with normal renal function did not change on 400 and $600 \mathrm{mg}$ single dose or on multiple administrations of ABK over a period of 7 days (Table 2 and Figure 7B). ${ }^{25}$ These data suggest that renal clearance and total clearance do not decrease at a high dose, and ABK has no tendency toward accumulation if renal function is normal.

\section{Pharmacokinetics in children}

Recommended initial dosing regimens were $5 \mathrm{mg} / \mathrm{kg}$ every 48 hours for preterm infants (postnatal age was within 28 days), $5 \mathrm{mg} / \mathrm{kg}$ every 24 hours for preterm infants (postnatal age was 28 days or more), and $4 \mathrm{mg} / \mathrm{kg}$ every 24 hours for term infants. These initial dosing regimens could manage the maximum concentration $\left(\mathrm{C}_{\max }\right) 7-15 \mu \mathrm{g} / \mathrm{mL}$ and trough concentration $\left(\mathrm{C}_{\text {trough }}\right) 0-2 \mu \mathrm{g} / \mathrm{mL}$ in $72.2 \%-93.5 \%$ of infant patients. ${ }^{26}$

Administration of ABK once daily in neonates has been investigated; the mean serum peak and $\mathrm{C}_{\text {trough }}$ of $\mathrm{ABK}$ were $15.2 \pm 4.3 \mu \mathrm{g} / \mathrm{mL}$ and $2.0 \pm 1.4 \mu \mathrm{g} / \mathrm{mL}$, respectively. Overall clinical effectiveness was $78.9 \%$ and no adverse effect was observed. During the period of administration, serum creatinine levels of some cases increased slightly, although the highest was $0.27 \mathrm{mg} / \mathrm{dL}$ but returned to baseline (predose value) promptly after stopping $\mathrm{ABK}$ administration. Therefore, it is supposed that ABK therapy once daily in neonates is a treatment option. ${ }^{27}$

\section{Distribution of ABK}

The PK-PD parameters of ABK in bronchial epithelial lining fluid (ELF) were investigated and the mean $\mathrm{C}_{\text {max }}$ in serum and bronchial ELF were $26.0 \pm 12.2$, and $10.4 \pm 1.9 \mu \mathrm{g} / \mathrm{mL}$, respectively. ${ }^{28}$ The ratio of concentrations of the drug in bronchial
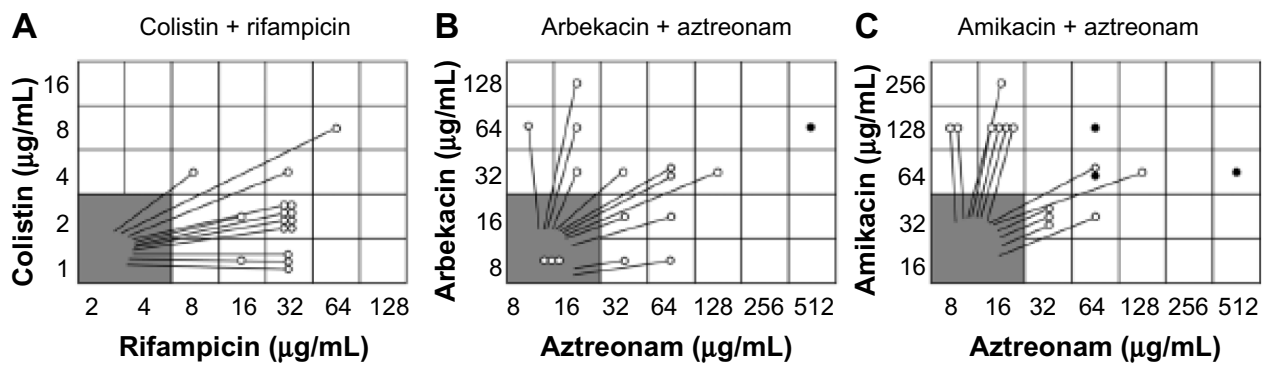

Figure 6 Results of Break-point Checkerboard Plate for (A) colistin plus rifampicin, (B) arbekacin plus aztreonam and (C) amikacin plus aztreonam. Notes: The gray area indicates the drug concentration using the Break-point Checkerboard Plate. The open circles indicate the strains judged as "effective" and the closed circles indicate the strains judged as "non-effective". 
Table 2 Pharmacokinetic parameters after administration of ABK

\begin{tabular}{|c|c|c|c|c|c|c|c|c|}
\hline Group & & $\begin{array}{l}C_{\max } \\
(\mu \mathrm{g} / \mathrm{mL})\end{array}$ & $\begin{array}{l}C_{\text {trough }} \\
(\mu \mathrm{g} / \mathrm{mL})\end{array}$ & $\mathrm{T}_{1 / 2}(\mathrm{hr})$ & $\begin{array}{l}\text { AUC }_{0-24} \\
(\mu \mathrm{g} \cdot \mathrm{hr} / \mathrm{mL})\end{array}$ & $\begin{array}{l}\mathrm{CL}_{\text {tot }} \\
(\mathrm{L} / \mathrm{hr})\end{array}$ & $\mathrm{V}_{\mathrm{ss}}(\mathrm{L})$ & Reference \\
\hline \multirow[t]{3}{*}{ All patients } & $\mathrm{n}$ & 17 & 17 & 12 & 12 & 12 & 12 & 24 \\
\hline & Mean \pm SD & $16.2 \pm 5.1$ & $1.1 \pm 1.7$ & $8.06 \pm 7.44$ & $103.1 \pm 66.4$ & $2.61 \pm 1.69$ & $15.3 \pm 3.6$ & \\
\hline & Min-max & $7.2-23.1$ & $0.0-5.3$ & $1.96-23.73$ & $36.5-222.4$ & $0.56-5.47$ & $10.4-20.2$ & \\
\hline Normal renal function & $\mathrm{n}$ & 10 & 10 & 5 & 5 & 5 & 5 & \\
\hline \multirow[t]{2}{*}{$80 \leqq C c r$} & Mean \pm SD & $15.2 \pm 5.7$ & $0.3 \pm 0.4$ & $3.5 I \pm 2.67$ & $58.6 \pm 22.5$ & $3.7| \pm| .3 \mid$ & $14.6 \pm 4.3$ & \\
\hline & Min-max & $7.2-23.1$ & $0.0-1.2$ & $1.96-8.3$ & $36.5-96.3$ & $\mathrm{I} .8 \mathrm{I}-5.47$ & $10.4-20.2$ & \\
\hline Mild renal dysfunction & $\mathrm{n}$ & 3 & 3 & 3 & 3 & 3 & 3 & \\
\hline \multirow[t]{2}{*}{$50 \leqq \mathrm{Ccr}<80$} & Mean \pm SD & $14.8 \pm 2.4$ & $0.2 \pm 0.3$ & $3.95 \pm 2.32$ & $62.9 \pm 18.0$ & $3.30 \pm 1.06$ & $15.9 \pm 3.9$ & \\
\hline & Min-max & $12.4-17.3$ & $0.0-0.6$ & $2.5 I-6.63$ & $45.6-81.5$ & $2.27-4.38$ & $11.6-19.3$ & \\
\hline Moderate to severe & $\mathrm{n}$ & 4 & 4 & 4 & 4 & 4 & 4 & \\
\hline renal dysfunction & Mean \pm SD & $19.8 \pm 3.7$ & $3.9 \pm 1.1$ & $16.82 \pm 6.02$ & $188.8 \pm 24.0$ & $0.7 \pm 0.14$ & $15.7 \pm 3.5$ & \\
\hline $\mathrm{Ccr}<50$ & Min-max & $14.6-23.1$ & $2.7-5.3$ & $10.27-23.73$ & $165.3-222.4$ & $0.56-0.87$ & $10.6-18.5$ & \\
\hline Dose & $n=8$ & $\begin{array}{l}C_{\max } \\
(\mu g / m L)\end{array}$ & $\begin{array}{l}C_{\text {peak }} \\
(\mu g / m L)\end{array}$ & $\begin{array}{l}T_{1 / 2} \\
(h r)\end{array}$ & $\begin{array}{l}\text { AUC }_{0 \text {-infinity }} \\
(\mu \mathrm{g} \cdot \mathrm{hr} / \mathrm{mL})\end{array}$ & $\begin{array}{l}\mathrm{CL}_{\text {tot }} \\
(\mathrm{L} / \mathrm{hr})\end{array}$ & $\begin{array}{l}V_{\text {ss }} \\
(L)\end{array}$ & Reference \\
\hline 400 mg Day 7 & Mean \pm SD & $44.4 \pm 5.3$ & $25.6 \pm 2.1$ & $6.4 \pm 1.7$ & $107.5 \pm 17.1$ & $3.8 \pm 0.6$ & $18.6 \pm 3.4$ & 25 \\
\hline 600 mg Day 7 & Mean \pm SD & $68.9 \pm 5.4$ & $38.0 \pm 2.8$ & $4.1 \pm 1.6$ & $149.9 \pm 12.9$ & $4.0 \pm 0.3$ & $14.5 \pm 2.8$ & \\
\hline
\end{tabular}

Abbreviations: $A B K$, arbekacin; $C c r$, creatinine clearance $(\mathrm{mL} / \mathrm{min}) ; \mathrm{SD}$, standard deviation; $\mathrm{C}_{\max }$, maximum concentration; $\mathrm{C}_{\text {trough }}$, trough concentration; $\mathrm{T}_{1 / 2}$, half-life; $A \mathrm{AC}$, area under the curve; $\mathrm{CL}_{\text {tot }}$, total clearance; min, minimum; max, maximum; Vss, distribution volume at steady state.

ELF to $\mathrm{C}_{\max }$ in serum was $0.465 \pm 0.188$. These data suggest that transitivity of $\mathrm{ABK}$ to the respiratory tract was relatively good, because transitivity of aminoglycosides to the lungs is about $30 \%$ in general. ${ }^{29}$

It has been reported that volume of distribution of aminoglycosides generally correlates with the extracellular fluid $^{30,31}$ and tissue fluids, such as interstitial fluid or synovial fluid, with a sufficient concentration of the drug infiltrating a surgical wound site and subcutaneous tissue. ${ }^{32-38}$ Distribution of $\mathrm{ABK}$ from circulating blood to a wound site was evaluated in patients with wound infection caused by $S$. aureus who were treated with $200 \mathrm{mg}$ of ABK once daily. In this study, high levels of distribution in the wound exudate, $46.2 \%-55.3 \%$, were observed. ${ }^{39}$

\section{Therapeutic drug monitoring of ABK}

Therapeutic drug monitoring (TDM) of $\mathrm{ABK}$ is required for maximizing efficacy while minimizing toxicities. In the population of patients with normal renal function, the target
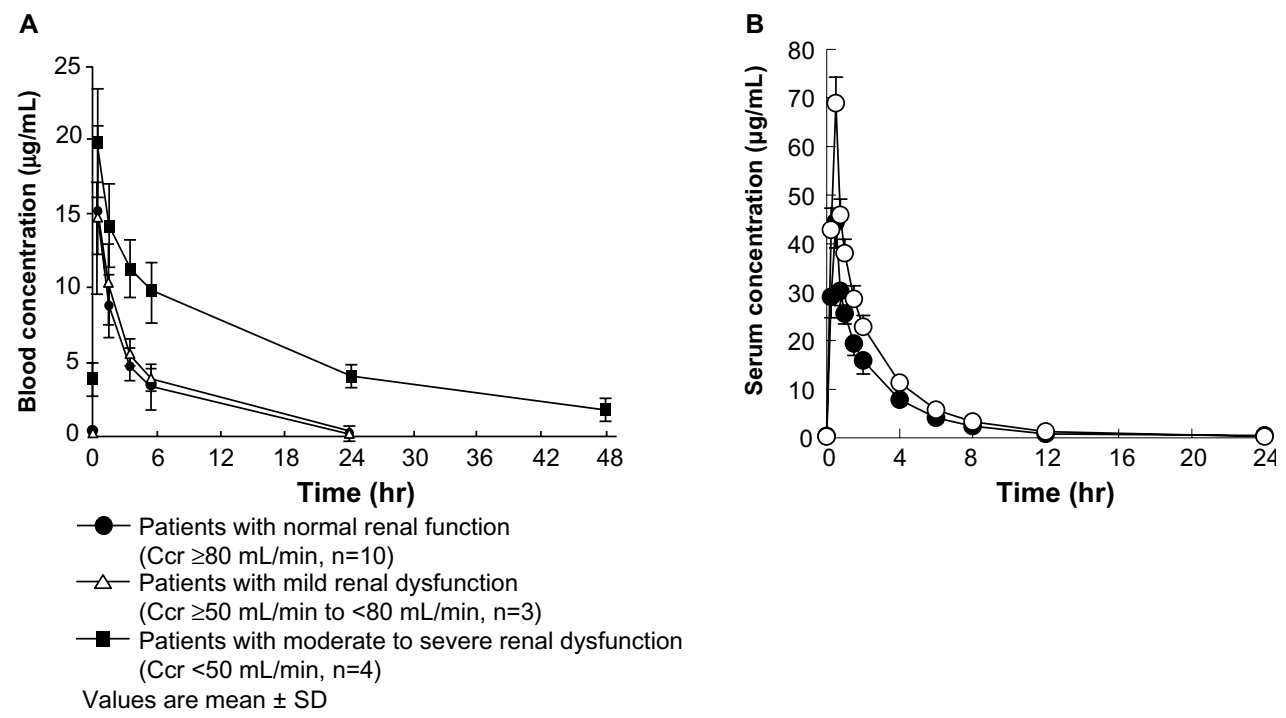

Figure 7 Plasma (serum) concentration after administration of $A B K$.

Notes: (A) Plasma concentration after administration of ABK $200 \mathrm{mg}$ for MRSA infected adult patients; (B) serum concentrations of ABK in healthy adults after multiple administrations of ABK $400 \mathrm{mg}$ (closed circles) or $600 \mathrm{mg}$ (open circles). Mean $\pm S D(n=8)$.

Abbreviations: ABK, arbekacin; MRSA, methicillin-resistant Staphylococcus aureus; SD, standard deviation; Ccr, creatinine clearance (mL/min). 
peak concentration $\left(\mathrm{C}_{\text {peak }}\right)$ value of $15-20 \mu \mathrm{g} / \mathrm{mL}$ was not achieved with once daily administration of 150-200 mg as the approved dose, and a higher dosing regimen is required to improve clinical efficacy. A clinical practice guideline for TDM of ABK was developed by the Japanese Society of Chemotherapy and the Japanese Society of Therapeutic Drug Monitoring. ${ }^{40}$ Experts recommend $300 \mathrm{mg} /$ day $(5.5-6.0 \mathrm{mg} / \mathrm{kg})$ to reach the target concentration.

\section{PK-PD parameters}

The PK-PD parameter of ABK which was associated with a therapeutic effect was $\mathrm{C}_{\text {max }} / \mathrm{MIC}$ and/or AUC/MIC, with a low correlation of efficacy observed in $\mathrm{T}>\mathrm{MIC}$, and the highest correlation coefficient observed in $\mathrm{C}_{\max } / \mathrm{MIC}{ }^{41-43}$ It was shown that the probability of cure/improvement rose when the $\mathrm{C}_{\max }$ of ABK was increased, with an odds ratio of 6.7 for a change in $\mathrm{C}_{\max }$ from $7.9-12.5 \mu \mathrm{g} / \mathrm{mL} .{ }^{44}$ In other studies, a key determinant of clinical efficacy of $\mathrm{ABK}$ was considered to be $\mathrm{C}_{\max } / \mathrm{MIC}$, and the appropriate $\mathrm{C}_{\max } / \mathrm{MIC}$ value which showed a good correlation between bacteriological efficacy was 8 or higher. ${ }^{44-48}$

\section{Clinical efficacy}

There are several reports on clinical efficacy, bacteriological efficacy, and safety against MRSA infection which compared the treatment of VCM and ABK. ${ }^{49,50}$ Hwang et $\mathrm{al}^{50}$ reported that the bacteriological efficacy responses of ABK and VCM were $71.2 \%$ and $79.5 \%$, respectively, and the clinical efficacy responses of those were $65.3 \%$ and $76.1 \%$, respectively, and that there was no statistically significant difference between ABK and VCM. The incidence of complications was significantly higher in the VCM group (32.9\%) in comparison with the ABK group $(15.1 \%)(P=0.019)$. ABK was not inferior to VCM, and it could be a good alternative drug for the treatment of MRSA infection. ${ }^{49}$ However, further prospective randomized trials are needed to confirm this finding. ${ }^{50}$

\section{Clinical trial for re-assessment of higher dose regimen}

There is a report on a clinical study to examine the efficacy and safety of $\mathrm{ABK}$ in patients with pneumonia or sepsis caused by MRSA. ${ }^{51}$ In this study, the target $\mathrm{C}_{\text {peak }}$ was initially set at $15-20 \mu \mathrm{g} / \mathrm{mL}$ and TDM was conducted. The efficacy rate was $87.5 \%$ (7/8 patients) for sepsis, $90.5 \%$ (19/21 patients) for pneumonia, and 89.7\% (26/29 patients) in total (Table 3).

Based on the results, it was recommended that the dosage regimen of $\mathrm{ABK}$ should be initially set at $5-6 \mathrm{mg} / \mathrm{kg}$ or higher, and adjusted to achieve $\mathrm{C}_{\text {peak }}$ at $10-15 \mu \mathrm{g} / \mathrm{mL}$ or higher and $\mathrm{C}_{\text {trough }}$ lower than $2 \mu \mathrm{g} / \mathrm{mL}$ for treatment of patients with MRSA pneumonia or sepsis. With this strategy, low incidence of adverse drug reactions and higher clinical efficacy would be achieved. As for clinical effects, the efficacy rates for sepsis and pneumonia observed in this study were higher than the $70 \%$ efficacy rate which was observed in two other studies. ${ }^{24,52}$ This high efficacy rate might be attributable to the higher concentration of ABK designed in this study. As the result of TDM intervention, the patients with higher $\mathrm{C}_{\text {peak }}$ at the final TDM than at the first TDM showed a 100\% efficacy rate.

A study in elderly patients with pneumonia or sepsis caused by MRSA after once daily administration of ABK at the mean dose of $269.2 \mathrm{mg}$ /day has been reported. ${ }^{53} \mathrm{C}_{\text {peak }}$ values for all patients, in whom ABK treatment had been

Table 3 Relationship between final daily dosage and efficacy/adverse drug reaction (ADR) rates

\begin{tabular}{|c|c|c|c|c|c|c|c|}
\hline \multirow{2}{*}{$\begin{array}{l}\text { Final daily dosage } \\
(\mathrm{mg} / \mathrm{kg})\end{array}$} & \multirow{2}{*}{$\begin{array}{l}\text { Type of } \\
\text { infection }\end{array}$} & \multirow[t]{2}{*}{$\mathrm{n} / 29$} & \multirow{2}{*}{\multicolumn{2}{|c|}{$\begin{array}{l}\text { Efficacy rate (\%)** } \\
89.7(26 / 29)\end{array}$}} & \multicolumn{2}{|c|}{ Incidence of ADRs (\%)* } & \multirow[t]{2}{*}{ Type of ADR } \\
\hline & & & & & 17.2 & $(5 / 29)$ & \\
\hline \multirow[t]{3}{*}{$<5$} & Sepsis & I & 0.0 & $(0 / I)$ & 100 & $(\mathrm{I} / \mathrm{I})$ & $\begin{array}{l}\text { Renal disorder, platelet } \\
\text { count decreased }\end{array}$ \\
\hline & Pneumonia & 8 & 87.5 & $(7 / 8)$ & 25.0 & $(2 / 8)$ & $\begin{array}{l}\text { Renal disorder, } \\
\text { constipation }\end{array}$ \\
\hline & Total & 9 & 77.8 & $(7 / 9)$ & 33.3 & $(3 / 9)$ & \\
\hline \multirow[t]{3}{*}{$\geq 5$ to $<6$} & Sepsis & 3 & 100 & $(3 / 3)$ & 0.0 & $(0 / 3)$ & \\
\hline & Pneumonia & 5 & 80.0 & $(4 / 5)$ & 20.0 & $(1 / 5)$ & Liver disorder \\
\hline & Total & 8 & 87.5 & $(7 / 8)$ & 12.5 & $(1 / 8)$ & \\
\hline \multirow[t]{3}{*}{$\geq 6$} & Sepsis & 4 & 100 & $(4 / 4)$ & 0.0 & $(0 / 4)$ & \\
\hline & Pneumonia & 8 & 100 & $(8 / 8)$ & 12.5 & $(1 / 8)$ & Elevated AST and ALT \\
\hline & Total & 12 & 100 & $(12 / 12)$ & 8.3 & $(1 / / 2)$ & \\
\hline
\end{tabular}

Notes: Eighty-nine patients from eleven clinical sites in Japan were enrolled in this clinical investigation, who in total were diagnosed with pneumonia or sepsis with MRSA infection or suspected MRSA infection. Among the patients, 29 adult patients who showed positive for MRSA detection following serum concentration analysis at the dose levels specified in the protocol were regarded as subjects for efficacy/safety analysis. Efficacy rate (\%): (effective)/(effective + not effective) $\times 100$. Incidence of ADRs (\%): (number of patients with ADRs)/(total patients) $\times 100$. *ADRs were observed in 5 patients. Incidence of ADRs was calculated by " 5 patients/29 patients". **The efficacy of ABK were observed in 26 patients. The efficacy rate was calculated by " 26 patients/29 patients".

Abbreviations: ABK, arbekacin; AST, aspartate aminotransferase; ALT, alanine aminotransferase; MRSA, methicillin-resistant Staphylococcus aureus. 
effective, were $15 \mu \mathrm{g} / \mathrm{mL}$ or higher. Their results and another report's results by Kimura et $\mathrm{al}^{54}$ suggest that therapy at high doses of $\mathrm{ABK}$ is recommendable even in old people, but that the control of $\mathrm{C}_{\text {trough }}$ is crucial.

\section{Combination therapy against multidrug-resistant Gram-negative bacteria}

The combined effect of aminoglycosides and monobactams was studied using the Break-point Checkerboard Plate against MDRP. ${ }^{55}$ Based on the result, a combination of AZT and ABK was selected as the anti-infective agent for MDRP treatment and the treatment result was reported. Since ABK also shows antibacterial activity against Gram-negative resistant bacteria, ABK as combination therapy can be used as a treatment option.

\section{Adverse effect of ABK}

Nephrotoxicity is a major adverse drug reaction to aminoglycoside antibiotics. ${ }^{56-59}$ The incidence of renal-related adverse drug reactions after administration of $\mathrm{ABK}$ was related to $\mathrm{C}_{\text {trough }}$. When $\mathrm{C}_{\text {trough }}$ was 1,2 or $5 \mu \mathrm{g} / \mathrm{mL}$, the estimated rate of adverse drug reactions were $2.5,5.2$, and $13.1 \%$ respectively, and the incidence of renal-related adverse drug reactions increased with a higher $\mathrm{C}_{\text {trough }}{ }^{44}$ The incidence of ABKinduced nephrotoxicity was observed in all patients when ABK was administrated at a total dose of over $5,000 \mathrm{mg}$, while it was $4 \%$ at a total dose of less than 5,000 mg. ${ }^{45}$

It is supposed that ototoxicity of aminoglycoside occurs because of the gradual drug accumulation of endolymph and perilymph in the inner ear. ${ }^{60-63}$ In addition, the results of some meta-analyses reported that there was no difference between single dosing and divided dosing in the incidence of ototoxicity. ${ }^{64,65}$ Yamasoba et al reported that the cochlea could easily be damaged by aminoglycoside antibiotics because of mitochondrial point mutation at location 1555 , and that hearing loss might occur with the administration of small amounts of aminoglycoside antibiotics. ${ }^{66,67}$ This might suggest that hearing loss might occur in a patient who is not taking aminoglycoside antibiotics, but that the hearing loss is due to a familial or hereditary condition.

\section{Conclusion}

ABK has been used for the treatment of MRSA infections for over 20 years in Japan and about 15 years in Korea. Clinical evidence achieved in these two countries revealed the safety and efficacy of this drug. Since ABK shows good antibacterial activity against Gram-negative bacteria in addition to MRSA, some physicians reported the high efficacy of ABK for the treatment of multidrug-resistant Gram-negative bacterial infections such as $A$. baumannii and $P$. aeruginosa. Therefore, it is expected that ABK will be a good potential antibiotic as an additional treatment option, such as in combination with beta-lactams (eg, AZT), for serious infections due to its potent antibacterial activities against both MRSA and multidrug-resistant Gram-negative bacteria.

\section{Disclosure}

T Matsumoto has served as a speaker for Pfizer Inc., Meiji Seika Pharma Co, Ltd, MSD Co, Ltd, and Dainippon Sumitomo Pharma Co, Ltd.

\section{References}

1. Kondo S. アルベカシンの開発とメチシリン而性黄色ブドウ球菌 による酵素的修飾をうけない新規誘導体の合成. [Development of arbekacin and synthesis of new derivatives stable to enzymatic modifications by methicillin-resistant Staphylococcus aureus]. Jpn J Antibiot. 1994;47(6):561-574. Japanese.

2. Tanaka N, Matsunaga K, Hirata A, Matsuhisa Y, Nishimura T. Mechanism of action of Habekacin, a novel amino acid containing aminoglycoside antibiotic. Antimicrob Agents Chemother. 1983;24(5):797-802.

3. Watanabe A, Yanagihara K, Matsumoto T, et al. Nationwide surveillance of bacterial respiratory pathogens conducted by the Surveillance Committee of Japanese Society of Chemotherapy, Japanese Association for Infectious Diseases, and Japanese Society for Clinical Microbiology in 2009: general view of the pathogens' antibacterial susceptibility. $J$ Infect Chemother. 2012;18(5):609-620.

4. Yamaguchi K, Ishii Y, Iwata M, et al. Meropenemを含む各種注 射用抗菌薬に対する2006年臨床分離株の感受性サーベイラ ンス. [Nationwide surveillance of parenteral antibiotics containing meropenem activities against clinically isolated strains in 2006]. Jpn J Antibiot. 2007;60(6):344-377. Japanese.

5. Nishino T, Sakurai M. In vitro activity of everninomicin (SCH 27899). In: Proceedings of the 33rd Interscience Conference on Antimicrobial Agents and Chemotherapy; October 17-20, 1993; Louisiana, New Orleans. Abstract No 462.

6. Okamoto R, Iyobe S, Mitsuhashi S. HBKの細菌学的検討 [Antibacterial activity of HBK]. Chemother. 1986;34:1-10. Japanese.

7. Kazuno Y, Tsuneta S, Tamra A, et al. Bactriological evaluation of a new aminoglycoside antibiotic, HBK. Chemother. 1986;34:61-71.

8. Matsuhashi Y, Yamamoto H. メチシリン・セフェム耐性黄色ブド ウ球菌の産生するアミノ配糖体系抗生物質不活化酵素に関す る研究 [The enzymatic mechanisms of resistant to aminoglycoside antibiotics in methicillin-cephem-resistant Staphylococcus aureus]. Jpn J Antibiot. 1988;41(5):523-529. Japanese.

9. Niki Y, Hanaki H, Yagisawa M, et al. Japanese Society of Chemotherapy. The first nationwide surveillance of bacterial respiratory pathogens conducted by the Japanese Society of Chemotherapy. Part 1: a general view of antibacterial susceptibility. J Infect Chemother. 2008;14(4):279-290.

10. Niki Y, Hanaki H, Matsumoto T, et al. Nationwide surveillance of bacterial respiratory pathogens conducted by the Japanese Society of Chemotherapy in 2007: general view of the pathogens' antibacterial susceptibility. J Infect Chemother. 2009;15(3):156-167.

11. Niki Y, Hanaki H, Matsumoto T, et al. Nationwide surveillance of bacterial respiratory pathogens conducted by the Japanese Society of Chemotherapy in 2008: general view of the pathogens' antibacterial susceptibility. J Infect Chemother. 2011;17(4):510-523.

12. Takesue Y, Watanabe A, Hanaki H, et al. Nationwide surveillance of antimicrobial susceptibility patterns of pathogens isolated from surgical site infections (SSI) in Japan. J Infect Chemother. 2012;18(6):816-826. 
13. Mikuniya T, Kato Y, Muto-Kobayashi Y, et al. Prevalence of drug resistant gene and changes in susceptibility of methicillin-resistant Staphylococcus aureus strains isolated from 1990 to 2006 in Japan to antimicrobial agents. Jpn J Chemother. 2009;61(5):37-40.

14. Watanabe T, Ohashi K, Matsui K, Kubota T. Comparative studies of the bactericidal, morphological and post-antibiotic effects of arbekacin and vancomycin against methicilin-resistant Staphylococcus aureus. J Antimicrob Chemother. 1997;39(4):471-476.

15. Flandrois JP, Fardel G, Carret G. Early stages of in vitro killing curve of LY146032 and vancomycin for Staphylococcus aureus. Antimicrob Agents Chemother 1988;32(4):454-457.

16. Asseray N, Jacqueline C, Le Mabecque V, et al. Activity of glycopeptides against Staphylococcus aureus infection in a rabbit endocarditis model: MICs do not predict in vivo efficacy. Antimicrob Agents Chemother. 2005;49(2):857-859.

17. Takahashi T, Matsumoto F, Miyazaki S. Comparison of in vitro antibacterial activity of arbekacin, vancomycin and teicoplanin against methicillin-resistant Staphylococcus aureus. Jpn J Chemother. 1999; 47(2):103-107.

18. Kurazono M, Yamada K, Hirai Y, Ida T, Inoue M. MRSA の疫学動向 と各種抗菌薬の抗菌活性について. [Epidemiological survey of drug resistance of methicillin-resistant Staphylococcus aureus isolated in Japan in 2000]. Jpn J Chemother. 2002;50(8):494-499. Japanese.

19. Miyata A, Araake M, Ogawa H, Hanaki H, Hiramatsu K. MRSAの Toxic shock syndrome toxin-1(TSST-1)産生に及ぼすarbekacinの作 用. [Effect of Arbekacin of the production of toxic shock syndrome toxin 1 by methicillin-resistant Staphylococcus aureus]. Jpn J Antibiotics. 2001;54(7):372-381. Japanese.

20. Araoka H, Baba M, Tateda $\mathrm{K}$, et al. In vitro combination effects of aztreonam and aminoglycoside against multidrug-resistant Pseudomonas aeruginosa in Japan. Jpn J Infect Dis. 2012;65(1):84-87.

21. Kataoka H, Ida T, Ishii Y, et al. Analysis of the influence of drug resistance factors on the efficacy of combinations of antibiotics for multidrug-resistant Pseudomonas aeruginosa isolated from hospitals located in the suburbs of Kanto area, Japan. Journal of Global Antimicrobial Resistance. 2013;1(2):91-96.

22. Zapor MJ, Barber M, Summers A, et al. In vitro activity of the aminoglycoside antibiotic arbekacin against Acinetobacter baumannii calcoaceticus isolated from war-wounded patients at Walter Reed Army Medical Center. Antimicrob Agents Chemother. 2010;54(7):3015-3017.

23. Overview of Habekacin Injectable Solution (additional pediatric indication). In-house document of Meiji Seika Kaisha, Ltd.

24. Aikawa N, Kohno S, Kaku M, WatanabeA, Yamaguchi K, Tanigawara Y. An open clinical study of arbekacin $200 \mathrm{mg}$ qd in patients infected with methicillin-resistant Staphylococcus aureus (MRSA) - A clinical pharmacology study. Jpn J Chemother. 2008;56(3):299-312.

25. Sunakawa K, Hori S. 健康成人男性におけるアルベカシン硫酸 塩400mg 又は600mg投与時の安全性及び薬物動態. [Safety and pharmacokinetics of 400 and $600 \mathrm{mg}$ arbekacin sulfate to healthy male volunteers]. Jpn J Antibiotics. 2013;66(2):97-109. Japanese.

26. Suzuki K, Tanikawa K, Matsuzaki T. Pharmacokinetics and dosing of arbekacin in preterm and term newborn infants. Pediatr Int. 2003;45(2):175-179.

27. Kinoshita D. 新しい推奨ピーク值を目標とした新生児に対する アルベカシン1日1回投与法の検討. [Evaluation of once a day of arbekacin administration to neonates as a new object of peak concentration]. Kansenshogaku Zasshi. 2010;84(6):727-733. Japanese.

28. Funatsu Y, Hasegawa N, Namkoong H, et al. Penetration of arbekacin sulfate to the lung tissue. Proceedings of the 52nd interscience conference on antimicrobial agents and chemotherapy; September 9-12, 2012; San Francisco. Abstract No 2068.

29. Carcas AJ, Garcia-Satue JL, Zapater P, Frias-Iniesta J. Tobramycin penetration into epithelial lining fluid of patients with pneumonia. Clin Pharmacol Ther. 1999;65(3):245-250.

30. Kimura T, Sunakawa K, Matsuura N, Kubo H, Shimada S, Yago K Population pharmacokinetics of arbekacin, vancomycin, and panipenem in neonates. Antimicrob. Agents Chemother. 2004;48(4):1159-1167.
31. Koga K, Kusawake Y, Ito Y, Sugioka N, Shibata N, Takada K. Enhancing mechanism of Labrasol on intestinal membrane permeability of the hydrophilic drug gentamicin sulfate. Eur J Pharm Biopharm. 2006;64(1):82-91.

32. Blaser J, Rieder HL, Luthy R. Interface-area-to-volume ratio of interstitial fluid humans determined by pharmacokinetic analysis of netilmicin in small and large skin blisters. Antimicrob Agents Chemother. 1991;35(5):837-839.

33. Dee TH, Kozin F. Gentamicin and tobramycin penetration into synovial fluid. Antimicrob Agents Chemother. 1977;12(4):548-549.

34. Thys JP, Serruvs-Schoutens E, Rocmans P, Herchuelz A, Vanderlinden MP, Yourassowsky E. Amikacin concentration in uninfected post thoracotomy pleural fluid and in serum after intravenous and intrapleural injection. Chest. 1984;85(4):502-505.

35. Kozak AJ, Gerding DN, Peterson LR, Hall WH. Gentamicin intravenous infusion rate: effect on interstitial fluid concentration. Antimicrob Agents Chemother. 1977;12(5):606-608.

36. Chisholm GD, Waterworth PM, Calnan JS, Garrod LP. Concentration of antibacterial agents in interstitial tissue fluid. Br Med J. 1973;1(5853): 569-573.

37. Lorentzen H, Kallehave F, Kolmos HJ, Knigge U, Bulow J, Gottrup F. Gentamicin concentrations in human subcutaneous tissue. Antimicrob Agents Chemoter. 1996;40(8):1785-1789.

38. Rosin E, Ebert S, Uphoff TS, Evans MH, Schultz-Darken NJ. Penetration of antibiotics into the surgical wound in a canine model. Antimicrob Agents Chemoter.1989;33(5):700-704.

39. Hayashi M, Ooi K, Yamada, et al. アルベカシン硫酸塩静注後の滲出 液中濃度と血中濃度を測定した4症例. [Arbekacin sulfate concentration in peripheral lymph and in serum after intravenous injection: report of four cases]. Jpn J Antibiot. 2012;65(3):207-215. Japanese.

40. Okada K, Kimura T, Mikamo H, et al. Clinical practice guidelines for therapeutic drug monitoring of arbekacin: A consensus review of the Japanese Society of Chemotherapy and the Japanese Society of Therapeutic Drug Monitoring. J Infect Chemother. 2014;20(1):1-5.

41. Shimizu A, Maebashi K, Niida M, et al. S03044. Pharmacokineticpharmacodynamic (PK-PD) study of arbekacin using mouse MRSA thigh infection model. In-house document of Meiji Seika Kaisha, Ltd; 2003.

42. Mattie H, Craig WA, Pechere JC. Determination of efficacy and toxicity of aminoglycosides. J Antimicrob Chemother. 1989;24(3): 281-293.

43. Craig WA. Pharmacokinetic/pharmacodynamic parameters: rationale for antibacterial dosing of mice and men. Clin Infect Dis. 1998;26(1): $1-12$.

44. Sato R, Tanigawara Y, Kaku M, Aikawa N, Shimizu K. Pharmacokineticpharmacodynamic relationship of arbekacin for treatment of patients infected with methicillin-resistant Staphylococcus aureus. Antimicrob Agents Chemother. 2006;50(11):3763-3769.

45. Negita K, Yamashita M, Kubota T, et al. Study on therapeutic drug monitoring of arbekacin in patients infected with methicillin-resistant Staphylococcus aureus and its efficacy. Jpn J Pharm Health Care Sci. 2001;27(2):123-131.

46. Nambara M, Ikeue H, Kawasaki E, Tomioka S, Shimokawa F, Tanabe K. Effectiveness and adverse reactions between once daily and every other day administration of arbekacin sulfate. Jpn J Ther Drug Monit. 2003;20(3):241-248.

47. Kobayashi M, Saikyo A, Soma K, Yago K, Sunakawa K. Pharmacokinetic and pharmacodynamics (PK-PD) analysis to determine the optimal method of arbekacin administration. Jpn J Chemother. 2006;54(1):18-24.

48. Tanikaze N, Komatsu M, Shimakawa K, Yamamoto I. メチシリン耐 性黄色ブドウ球菌肺炎に対する硫酸アルベカシン治療における $\mathrm{PK} / \mathrm{PD}$ 解析の臨床的有用性. [Study of clinical significance of PK/PD (pharmacokinetics/pharmacodynamics) parameters after administering arbekacin to patients with pulmonary methicillin-resistant Staphylococcus aureus infection]. Jpn J Chemother. 2004;52(9):469-473. Japanese. 
49. Hwang JH, Lee JH, Moon MK, Kim JS, Won KS, Lee CS. The usefulness of arbekacin compared to vancomycin. Eur J Clin Microbiol Infect Dis. 2012;31(7):1663-1666.

50. Hwang JH, Lee JH, Moon MK, Kim JS, Won KS, Lee CS. The efficacy and safety of arbekacin and vancomycin for the treatment in skin and soft tissue mrsa infection: preliminary study. Infect Chemother. 2013;45(1):62-68.

51. Matsumoto T, Hanaki H, Kimura T, et al. Clinical efficacy and safety of arbekacin sulfate in patients with MRSA sepsis or pneumonia: a multi-institutional study. J Infect Chemother. 2013;19(1): 128-137.

52. Kawano H, Tanigawara Y. Postmarketing surveillance review of arbekacin sulfate in patients with therapeutic drug monitoring. Jpn JTher Drug Monit. 2010;27(2):55-71.

53. Yamamoto Y, Izumikawa K, Hashiguchi K, et al. The efficacy and safety of high-dose arbekacin sulfate therapy (once-daily treatment) in patients with MRSA infection. J Infect Chemother. 2012;18(2):241-246.

54. Kimura T, Sunakawa K, Totsuka K, et al. Dose finding study on arbekacin sulfate for appropriate peak levels. Jpn J Chemother. 2011;59(6): 597-604.

55. Araoka H, Baba M, Takagi S, et al. Monobactam and aminoglycoside combination therapy against metallo-beta-lactamase-producing multidrug-resistant Pseudomonas aeruginosa screened using a 'break-point checkerboard plate'. Scand J Infect Dis. 2010;42(3):231-233.

56. Mingeot-Leclercq MP, Tulkens PM. Aminoglycosides: nephrotoxicity. Antimicrob Agents Chemother. 1999;43(5):1003-1012.

57. Swan SK. Aminoglycoside nephrotoxicity. Semin Nephrol. 1997;17(1): 27-33.

58. Giuliano RA, Verpooten GA, Verbist L, Wedeen RP, De Broe ME. In vivo uptake kinetics of aminoglycosides in the kidney cortex of rats. J Pharmacol Exp Ther. 1986;236(2):470-475.
59. Rougier F, Claude D, Maurin M, et al. Aminoglycoside nephrotoxicity: modeling, simulation, and control. Antimicrob Agents Chemother. 2003;47(3):1010-1016.

60. Chanbers HE. Chemotherapy of microbial diseases antimicrobial agents: the aminoglycosides. In: Hardman JG, Limbird LE, editors. Goodman and Gilman's The Pharmacological Basis of Therapeutics, 10th edition. New York: McGraw-Hill; 2001:1219-1238.

61. Huy PTB, Mannel C, Menlemans A. Kinetics of aminoglycoside antibiotics in perilymph in animals. In: Lerner SA, Martz GJ, Hawkins JE, editors. Aminoglycoside Ototoxicity. Little, Brown and Company; 1981; 81-97.

62. Tulkens PM, Clerckx-Braun F, Donnez J, et al. Safety and efficacy of aminoglycosides once-a-day: experimental data and randomized, controlled evaluation in patients suffering from pelvic inflammatory disease. J Drug Dev. 1988;1(Suppl 3):71-82.

63. Totsuka K, Shimizu K, Mitomi N, Niizato T, Araake M. Arbekacinの 1日1回投与法の検討 基礎的検討及びヒトにおける体内動態. [Evaluation of once-daily administration of arbekacin]. Jpn J Antibiotics. 1994;47(6): 676-692. Japanese.

64. Bates DE. Aminoglycoside ototoxicity. Drugs Today (Barc). 2003; 39(4):277-285.

65. Barclay ML, Kirkpatrick CM, Begg EJ. Once daily aminoglycoside therapy - Is it less toxic than multiple daily doses and how should it be monitored? Clin Pharmacokinet. 1999;36(2):89-98.

66. Yamasoba T. Inner ear disorders and mitochondrial DNA mutation. Practica Oto-Rhino-Laryngologica. 2011;104(8):533-540.

67. Hamasaki K, Rando RR. Specific binding of aminoglycosides to a human rRNA construct based on a DNA polymorphism which causes aminoglycoside-induced deafness. Biochemistry. 1997;36(40): $12323-12328$.
Clinical Pharmacology: Advances and Applications

\section{Publish your work in this journal}

Clinical Pharmacology: Advances and Applications is an international, peer-reviewed, open access journal publishing original research, reports, reviews and commentaries on all areas of drug experience in humans. The manuscript management system is completely online and includes a very quick and fair peer-review system, which is all easy to use.

\section{Dovepress}

Visit http://www.dovepress.com/testimonials.php to read real quotes from published authors. 